\title{
Historia kurateli sądowej w Polsce - uwarunkowania organizacyjno-prawne
}

\section{The history of court guardianship in Poland - organizational and legal conditions}

\begin{abstract}
Streszczenie:
Artykuł powstał w związku z upamiętnieniem obchodów 100-lecia kurateli sądowej w Polsce. Tekst ma wymiar przeglądowy i popularyzatorski - autor przedstawia istotne momenty (kroki) w rozwoju instytucji kurateli sądowej - od 1919 roku do uchwalenia Ustawy o kuratorach sądowych w 2001 roku.

Słowa kluczowe: historia, kuratela sądowa
\end{abstract}

\begin{abstract}
:
This paper was written to commemorate the 100th anniversary of the introduction of court guardianship in Poland. The text has a review and popularizing dimension - the author presents the most important moments (steps) in the history of court guardianship - from 1919 till the introduction of The Act on Probation Officers in 2001.
\end{abstract}

Keywords: history, court guardianship

\section{Wprowadzenie}

Historia kurateli sądowej w Polsce jest „nieco” krótsza, niż ta w Europie, czy na świecie. W kontekście tegorocznych obchodów 100lecia kurateli sądowej w Polsce, myślę, że warto przyjrzeć się istotnym momentom w historii rozwoju tej instytucji w naszym kraju. 
Paweł Sobierajski - Historia kurateli sq̨dowej...

Rok 1919 uznany został właśnie za ten zamykający stulecie kurateli sądowej - w kolejnych akapitach przedstawiam uzasadnienie, które stoi za takim stanowiskiem. W tym miejscu uruchamiamy dywagacje na temat cezury: jakie wydarzenia można uznać za istotne, czy wręcz przełomowe dla powstania i rozwoju tej instytucji? Oraz - czy rzeczywiście rok 1919 to początek kurateli w Polsce? Oczywiście, nie jest moim zamiarem kontestacja tej ostatniej daty, a jedynie chęć zwrócenia uwagi na uwarunkowania i okoliczności, jakie brane były/ są pod uwagę przy oznaczaniu początków tej instytucji.

W analizie historii rozwoju instytucji społecznych przyjmuje się różne wyznaczniki, najczęściej: 1) praktykę w danym obszarze życia społecznego; 2) pierwsze użycie i ukonstytuowanie nazwy opisującej dany ruch, zjawisko, czy instytucję. Gdyby - dla porównania - spojrzeć na historię kurateli sądowej na świecie przez pryzmat pierwszego wyznacznika, jakim jest praktyka w danym obszarze życia społecznego, to za początki kurateli sądowej najczęściej uznaje się przywoływaną praktykę Johna Augustusa, szewca z Bostonu, który - jak donoszą różne źródła - w 1841 roku w stanie Massachusetts udzielił poręczenia za mężczyznę oskarżonego o pijaństwo w miejscu publicznym. W tamtym przypadku, jak donoszą różne zapisy, sąd powstrzymał się od wymierzenia kary, wyznaczył okres próby i oddał na ten czas podsądnego pod opiekę wspomnianej wcześniej osoby. Ponieważ efekty tego „dozoru” były w opinii sądu zadowalające, postanowiono taką praktykę stosować także w przypadkach¹.

Łatwiej zapewne operować cezurą wynikającą z powstawania określonych przepisów prawnych - takich, które wprost powoływały instytucję kurateli sądowej. Tonem więc zamknięcia tego wątku porównawczego można wspomnieć o ustawie z 1869 r. w USA (w stanie

1 J. Skupiński, Warunkowe skazanie w prawie polskim na tle porównawczym, Warszawa 1992, s. 24-25; Por. A. Marek, Rola amerykańskiej probacji i jej efektywność, „Acta Universitatis Nicolai Copernici. Prawo XVI" 1978, z. 89, s. 217; P. Stępniak, Funkcjonowanie kurateli sq̨dowej. Teoria a rzeczywistość, Wyd. UAM, Poznań 1992, s. 26; M. Kalinowski, Nadzór kuratora sq̨dowego - formq wychowania resocjalizacyjnego, [w:] K. Pospiszyl (red.), Resocjalizacja nieletnich. Doświadczenia i koncepcje, WSiP, Warszawa 1990, s. 285. 
Massachusetts; dotyczyła wyłącznie nieletnich), w której po raz pierwszy pojawia się instytucja kuratora (dla nieletnich), czy o Probation of Offenders Act, ustanawiającej w 1907 roku, jeszcze fakultatywnie, kuratelę sądową w Anglii (a także Szkocji i Irlandii)².

\section{Krok pierwszy - powołanie instytucji opiekuna sądowego}

Wróćmy do tematu i do Polski, a raczej do ziem polskich i czasów zaborów. Tam bowiem odnajdujemy pierwsze sygnały rodzącej się idei kurateli sądowej. Początków kurateli sądowej w Polsce należałoby poszukiwać - tak jak to miało miejsce i w innych krajach europejskich (przede wszystkim Belgii i Francji ${ }^{3}$ ) - w pojawiającej się w prawie karnym instytucji warunkowego skazania oraz warunkowego przedterminowego zwolnienia (określanego wówczas „warunkowym uwolnieniem”). W 1889 roku w „Gazecie Sądowej Warszawskiej” ukazał się artykuł M. Korenfelda, w którym autor podjął się analizy tej instytucji podnosząc zasadność jej wprowadzenia do obowiązującego ówcześnie prawa4. W tym samym roku i na łamach tego samego pisma E. Krzymuski ogłosił opracowanie pt. $O$ uwolnieniu warunkowem $i$ warunkowych wyrokach skazujących z powodu Ustawy Belgijskiej z dnia 31 Maja $1888 r r^{5}$. Tam też pojawiły się pierwsze informacje na temat angielskiego systemu „probation” i kuratorów sądowych. Tak więc możemy przyjąć, że instytucje te były dobrze znane w polskim piśmiennictwie, jednak $\mathrm{z}$ uwagi na warunki polityczne (brak

2 Zob. J. Skupiński, Warunkowe skazanie..., op. cit., s. 35-38; A. Marek, Środki probacyjne, [w:] A. Marek et al. (red.), Prawo karne, Warszawa 1986., s. 202; A. Mościskier, System kuratorski i opieki postpenitencjarnej w Anglii i Walii, „Prace Instytutu Profilaktyki Społecznej i Resocjalizacji UW" 1985, t. 9, s. 43.

3 Zob. P. Stępniak, Funkcjonowanie kurateli sq̨dowej, op. cit. s. 32-39.

${ }^{4}$ M. Korenfeld, Zamiast kary, „Gazeta Sądowa Warszawska” 1889, nr 2, s. 17 i nast., [za: J Skupiński, Warunkowe skazanie..., op. cit., s. 55.

5 „Gazeta Sądowa Warszawska” 1889, nr 33, s. 516 i nast.; S. Holewiński, $O$ warunkowem skazaniu, „Ateneum” 1897, t. III, s. 225-226, [za:] J Skupiński, Warunkowe skazanie..., op. cit., s. 58. 
Paweł Sobierajski - Historia kurateli sq̨dowej...

niepodległości) pozostawały tylko w sferze projektów i rozważań teoretycznych.

Warto jednak odnotować, iż na ziemiach polskich - szczególnie zaboru rosyjskiego - pojawiło się szereg inicjatyw społecznych skierowanych na pomoc więźniom opuszczającym zakłady karne. W 1909 r. w Królestwie Polskim zaczęła obowiązywać ustawa $O$ uwolnieniu warunkowym przed odbyciem terminu kary. $\mathrm{W}$ tym samym roku powstało też Towarzystwo Opieki nad Zwolnionymi z Więzień „Patronat”, które wśród postawionych sobie zadań wymieniało także pracę wychowawczą z osobami opuszczającymi więzienia6.

W 1916 roku ukazał się projekt kodeksu karnego A. Mogilnickiego i E. Rappaporta, który w założeniu miał stanowić akt prawny, który będzie obowiązywał w niepodległym kraju. Zasługuje on na uwagę ze względu na to, że w jego treści znajdujemy zapis (art. 36) powołujący instytucję „opiekuna społecznego" wyraźnie nawiązujący do idei kurateli sądowej. Stanowił on, iż w sytuacji orzeczenia warunkowego zawieszenia kary skazany w okresie próby (od 3 do 5 lat) miał obligatoryjnie pozostawać pod „dozorem opiekuńczym specjalnego opiekuna sądowego, który czuwa nad ich sprawowaniem i udziela im wskazówek". Na opiekuńczy charakter tegoż dozoru wskazywała dalsza treść wspomnianego artykułu, według której opiekunowi sądowego nie wolno było podopiecznych „do niczego zmuszać, ograniczać ani krępować ich ruchów"7. Projekt ten zawężał jednak stosowanie instytucji warunkowego skazania do osób w wieku do 21 lat - pamiętajmy jednakże, że ówczesna kodyfikacja tę kategorię wiekową obejmowała wspólnym terminem „nieletni”.

Można przyjąć, że właśnie te zapisy, jeszcze wówczas projektowe, stały się zalążkiem instytucji kuratora sądowego. W tym też kierunku poszły regulacje prawne w niepodległej Polsce. I znowu podobnie jak w innych krajach europejskich, instytucja kurateli sądowej pojawiła się wraz z ukonstytuowaniem sądownictwa dla nieletnich. Najpierw

${ }^{6}$ J. Kamiński, S. Milewski, Resocjalizacja skazanych. Poradnik dla kuratorów sq̨dowych, Warszawa 1979, s. 17.

${ }^{7}$ Cyt. za: J. Skupiński, Warunkowe skazanie..., op. cit., s. 59. 
Dekret Naczelnika Państwa z 8 lutego 1919 r. w przedmiocie utworzenia sądów dla nieletnich ${ }^{8}$ a później Rozporzq̨dzenie Ministra Sprawiedliwości z 26 lipca 1919 r. w przedmiocie urzq̨dzenia sq̨dów dla nieletnich ${ }^{9}$, powoływały instytucję tzw. opiekuna sądowego.

Powracam do dywagacji z początku tej części opracowania, gdzie stawiam pytanie, czy rok 1919 oznacza początek omawianej instytucji. De facto ani w Dekrecie Naczelnika Państwa, ani w późniejszym (z tego samego roku) Rozporządzeniu Ministra Sprawiedliwości, nie pada termin „kurator sądowy”. Nazwa ta pojawia się dopiero 10 lat później.

Trudno jednak nie uznać - i taką wykładnię między innymi przyjęła m. in. Krajowa Rada Kuratorów planując obchody 100-lecia - że powołana w 1919 roku instytucja opiekuna sądowego stanowi początek kurateli sądowej w Polsce. Wskazują na to dość jednoznacznie zapisy ww. rozporządzenia. Czytamy w nim między innymi, że opiekunów sądowych powoływać mają sędziowie, że mogą to być osoby obojga płci, że będą z tego tytułu pobierali „wynagrodzenie stałe z funduszów dyspozycyjnych sądu"10. Możemy odnaleźć w nim również zapisy mówiące o zadaniach, jakie mają wypełniać opiekunowie sądowi. Według nich opiekunowie sądowi „będą podlegali dyrektywie sędziego według wydanej instrukcji, jako jego pomocnicy w zbieraniu informacji o nieletnich, zajmą się w wypadkach przez sędziego wskazanych opieką nad nieletnim, niepozostającym pod dozorem rodzicielskim, lub gdy dozór rodzicielski wymaga jeszcze dodatkowej kontroli odpowiedzialnej, oraz będą mieli nadzór nad nieletnimi, skazanymi na karę, a korzystającymi z prawa zawieszenia kary"11. Nadzór opiekuna sądowego mógł być także orzeczony w sytuacji pozbawienia władzy nad nieletnim i oddania go pod opiekę innej rodzinie („zasługującej na zupełne zaufanie") ${ }^{12}$.

\footnotetext{
${ }^{8}$ Dz. Pr. P. P. 1919 Nr 14, poz. 171.

${ }^{9}$ Dz. Pr. P. P. 1919 Nr 63, poz. 378.

${ }^{10}$ Art. 3. Rozporządzenia Ministra Sprawiedliwości z 26 lipca 1919 r.

11 Ibidem.

12 Ibidem, art. 8.
} 
Paweł Sobierajski - Historia kurateli sq̨dowej...

Jeszcze większe uszczegółowienie zadań odnaleźć można w tzw. Instrukcji dla Opiekunów Sądowych przy Sądzie Pokoju dla nieletnich m. st. Warszawy, stworzonej przez sędziego Antoniego Komorowskiego w 1925 roku $^{13}$. Dodajmy na marginesie, że instytucja opiekuna sądowego mogła być powołana przy sądach pokoju w Warszawie, Łodzi i Lublinie, zgodnie z zapisem art. 1 przywoływanego wcześniej Dekretu Naczelnika Państwa z 8 lutego 1919 r.

Instrukcja dla Opiekunów Sq̨dowych... zawierała 17 paragrafów i stanowiła swego rodzaju metodykę pracy opiekuna sądowego. Wskazywała na rozległe zadania opiekunów sądowych, pokazując jak bardzo charakter ich pracy przypominał to, co leży współcześnie w gestii kuratorów sądowych. Bez większego wahania można przyjąć, że ówczesny opiekun sądowy miał realizować zadania o charakterze i wychowawczo-resocjalizacyjnym, i diagnostycznym, i profilaktycznym i kontrolnym - a więc to, o czym mówi art. 1 obecnie obowiązującej ustawy o kuratorach sądowych ${ }^{14}$.

\section{Krok drugi - powołanie instytucji kuratora nieletnich}

W 1929 roku kolejne rozporządzenie Ministra Sprawiedliwości ustanawiało w miejsce opiekuna sądowego instytucję kuratorów nieletnich przy sądach grodzkich i sądach dla nieletnich ${ }^{15}$. Dodajmy, że w roku 1935 kolejne rozporządzenie zlikwidowało instytucję kuratorów zawodowych, pozostawiając jedynie kuratorów społecznych.

\footnotetext{
13 A. Komorowski, Praktyczna działalność Koła Opiekunów Sądowych przy Sązie dla nieletnich m. st. Warszawy, [w:] A. Komorowski, E. Neymark, Z. Rosenblum, O sądownictwie dla nieletnich w Polsce, Dział Wydawnictw Związku Spółdzielni Spożywców, Warszawa 1928, s. 25-28. Por. K. Szymków, Instytucja stałych opiekunów sq̨dowych 1919-1929, „Folia Iuridica Universitatis Wratislaviensis” 2018, vol. 7 (1), s. 70-75.

14 Zadania opiekunów sądowych i ich realizację szczegółowo opisuje Krzysztof Szymków, zob. Idem, Instytucja stałych opiekunów..., op. cit., s. 67-80.

15 Rozporządzenie Ministra Sprawiedliwości z 25 czerwca 1929 r. w sprawie przekształcenia instytucji opiekunów sądowych na kuratorów nieletnich przy sądach grodzkich i przy sądach dla nieletnich, Dz.U. nr 47, poz. 387. Por.: K. Marzec-Holka, Instytucja społecznych kuratorów sądowych w świetle badań, Bydgoszcz 1994, s. 148.
} 
Stan ten utrzymywał się aż do 1959 roku, kiedy to ukazały się trzy akty prawne dotyczące kurateli sądowej dla nieletnich:

1) Rozporządzenie Ministra Sprawiedliwości z 13 lutego 1959 r. o kuratorach sądowych dla nieletnich ${ }^{16}$.

2) Rozporządzenie Ministra Sprawiedliwości z 1 kwietnia 1959 r. w sprawie wynagradzania kuratorów zawodowych dla nieletnich ${ }^{17}$.

3) Zarządzenie Ministra Sprawiedliwości z 10 kwietnia 1959 r. instrukcja w sprawie kuratorów sądowych dla nieletnich ${ }^{18}$.

Wyżej wymienione dokumenty określały nowy status kuratora sądowego (zawodowego i społecznego) w tamtym czasie.

W uzupełnieniu warto dodać, że obok instytucji kuratora nieletnich, już od 1956 roku funkcjonowała instytucja inspektora społecznego przy sądzie powiatowym, który posiadał uprawnienia zbieżne z tymi, które zostały określone dla kuratorów przepisami z 1959 roku $^{19}$. W związku z tym, w 1973 roku, obie te instytucje - inspektora społecznego i kuratora dla nieletnich - uległy połączeniu, a kurator nieletnich stał się pomocniczym organem sądu w sprawach nieletnich i w sprawach opiekuńczych małoletnich ${ }^{20}$.

Warto zwrócić uwagę na jeszcze dwa, istotne dla kurateli nad nieletnimi, momenty w historii (uwzględniając okres do 1986 roku będzie o tym mowa w dalszej części opracowania):

a) powołanie w 1978 roku sądów rodzinnych - kuratorzy zostali związani organizacyjnie z tymi sądami21;

16 Dz.U. 1959, Nr 18, poz. 113.

17 Dz.U. 1959, Nr 26, poz. 164.

18 Zbiór resortowych aktów prawnych Ministerstwa Sprawiedliwości, tom I, poz. 121, [cyt. za:] K. Stasiak, Ewolucja kurateli sq̨dowej od poczq̨tku do wejścia w życie rozporzqdzenia z $1986 r$, [w:] T. Jedynak, K. Stasiak (red.), Zarys metodyki pracy kuratora sq̨dowego, Wyd. Lexis-Nexis, Warszawa 2014, s. 21-22.

19 Rozporządzenie Ministra Sprawiedliwości z 3 lipca 1956 r. o inspektorach społecznych przy sądach powiatowych, Dz.U. 1956, Nr 29, poz. 134.

${ }^{20}$ Rozporządzenie Ministra Sprawiedliwości z 3 maja 1973 r. w sprawie kuratorów nieletnich, Dz.U. 1973, Nr 18, poz. 107.

21 Por. K. Stasiak, Ewolucja kurateli sq̨dowej..., op. cit., s. 23. 
Paweł Sobierajski - Historia kurateli sq̨dowej...

b) wejście w życie w dniu 13 maja 1983 roku ustawy o postępowaniu w sprawach nieletnich; zmieniała ona zarówno stan prawny dotyczący zasad funkcjonowania sądów rodzinnych, jak i regulacja zagadnień związanych z szeroko pojętym przeciwdziałaniem demoralizacji i przestępczości nieletnich.

\section{Krok trzeci - powstanie kurateli sądowej dla dorosłych}

Z dużo większymi problemami spotkało się wprowadzenie kurateli sądowej dla dorosłych. Instytucja ta co prawda pojawiła się w projektach Komisji Kodyfikacyjnej RP pracującej w latach 1921-31 nad kodeksem karnym - jego projektodawcy uznając fakultatywność dozoru przy orzeczeniu warunkowego skazania uznali, iż winien on być powierzony osobom lub instytucjom zasługującym na zaufanie. Taki też zapis znalazł się w kodeksie karnym z 1932 roku²2, jednak pozostał na takim poziomie ogólności, a ustawa nie stwarzała możliwości do wydania aktu wykonawczego szczegółowiej regulującego tę kwestię. Jedynie J. Makarewicz w Komentarzu do kodeksu karnego zwracał uwagę na to, iż dozór ochronny nie powinien być urzędowy, ani też policyjny ${ }^{23}$.

Jak pisze J. Skupiński: „Przepis o możliwości oddania skazanego pod dozór pozostawał (...) martwy i instytucja ta nie była stosowana w Polsce aż do początku lat sześćdziesiątych. W kwestii zorganizowanego dozoru nie wydano żadnego aktu ministerialnego, a do poddania sprawcy pod dozór «godnej zaufania» osoby lub instytucji (...) sądy w ogóle nie sięgały" 24 .

Lata 1945-1956 to okres zaostrzenia polityki karnej: surowych kar bezwzględnego pozbawienia wolności oraz zawężenia zakresu dopuszczalności instytucji warunkowego skazania. W 1951 roku uchylo-

\footnotetext{
22 Rozporządzenie Prezydenta RP z 11 lipca 1932 r. - Kodeks karny, Dz.U. RP nr 60, poz. 571.

${ }^{23}$ J. Makarewicz, Kodeks karny z komentarzem, Lwów 1938, s. 231. Zob. J. Skupiński, op. cit., s. 79.

24 J. Skupiński, op. cit., s. 85-86.
} 
ne też zostały przepisy (z 1932 r.) o warunkowym przedterminowym zwolnieniu i zastąpione nowymi - nie przewidującymi instytucji dozoru ochronnego (w zamian wprowadzono kontrolę zachowania skazanego sprawowaną przez prokuratora) i pozostawiającymi możliwość jego (tj. warunkowego zwolnienia) orzekania tylko Prokuratorowi Generalnemu PRL.

Istotne zmiany przyniósł rok 1957 . Wydana w tym roku ustawa ${ }^{25}$ uchyliła poprzednią i przywróciła możliwość oddania skazanego pod nadzór ochronny; wprowadziła także rozszerzony katalog obowiązków, które można było nałożyć na dozorowanego w okresie próby. Zawierała ona też delegację dla Ministra Sprawiedliwości do określenia - w drodze rozporządzenia - osób i instytucji upoważnionych do sprawowania nadzoru, trybu ich powoływania, uprawnień oraz sposobu wykonywania nadzoru.

Takie rozporządzenie wydane zostało w 1958 r. i było aktem po raz pierwszy ustanawiającym instytucję kuratorów dla warunkowo zwolnionych dorosłych ${ }^{26}$. Pełna nazwa brzmiała: „kuratorzy sądowi dla nadzoru nad warunkowo zwolnionymi", a w myśl rozporządzenia byli oni „społecznym organem pomocniczym” powoływanym przy sądach wojewódzkich. Kolejne rozporządzenie Ministra Sprawiedliwości z 1961 r., wzorując się na rozporządzeniu wydanym w sprawie warunkowo zwolnionych, powoływało odrębną grupę kuratorów dla sprawowania dozoru nad warunkowo skazanymi „kuratorzy sądowi dla dozoru ochronnego nad osobami, względem których wykonania kary pozbawienia wolności warunkowo zawieszono z jednoczesnym oddaniem tych osób pod dozór ochronny". Był to również organ społeczny powoływany przy sądach wojewódzkich i powiatowych podlegający właściwemu prezesowi sądu. W myśl obu wyżej wymienionych rozporządzeń kandydat na kuratora musiał spełniać następujące warunki: obywatelstwo polskie, ukończone 30 lat,

\footnotetext{
25 Ustawa z 29 maja 1957 r. o warunkowym zwolnieniu osób odbywających karę pozbawienia wolności, Dz.U. nr 31, poz. 134.

${ }^{26}$ Rozporządzenie Ministra Sprawiedliwości z 15 stycznia 1958 r. w sprawie nadzoru nad warunkowo zwolnionymi, Dz.U. nr 10, poz. 35.
} 
Paweł Sobierajski - Historia kurateli sq̨dowej...

niekaralność sądowa, pełnia praw publicznych, stałe zamieszkanie. Zadaniem kuratora była kontrola wywiązywania się przez skazanego z obowiązków próby, udzielanie rad i pomocy w rozwiązywaniu trudności życiowych. Do najważniejszych obowiązków należał osobisty kontakt z podopiecznym, niezwłoczne zawiadomienie sądu w przypadku zaistnienia okoliczności uzasadniających odwołanie zawieszenia bądź warunkowego zwolnienia, składanie sądowi kwartalnych sprawozdań z przebiegu okresu próby ${ }^{27}$. Warunki te, a przede wszystkim praktyka, wyraźnie każą określić charakter tak wówczas sprawowanej kurateli jako represyjno-kontrolny, ograniczony do czynności sprawdzających i ewentualnych działań o charakterze restrykcyjnym w stosunku do osób nie realizujących obowiązków nałożonych wyrokiem.

W 1965 r. nastąpił kolejny istotny krok na drodze budowania służby kuratorskiej dla dorosłych. Rozporządzenie wydane w tym roku uchylało poprzednie i łączyło obie kategorie dozoru ustanawiając tym samym jedną służbę kuratorską - „kuratorów sądowych”28. Po raz pierwszy też stwarzało ono możliwość powoływania przy sądach wojewódzkich kuratorów zawodowych. Całkowity ciężar nadal jednak miał spoczywać na kuratorach społecznych, którzy - w świetle obowiązujących przepisów - mogli sprawować jednocześnie nie więcej niż 10 dozorów. Do obowiązków kuratora zawodowego należało natomiast organizowanie i kontrola ich pracy oraz współpraca z innymi organami i instytucjami. Bezpośrednia praca ze skazanymi dotyczyła tylko szczególnie trudnych przypadków w obszarze warunkowo zwolnionych.

Lata sześćdziesiąte to zmiana polityki karnej wyrażająca się w łagodzeniu represji karnej oraz $\mathrm{w}$ dostrzeżeniu funkcjonalności środków karnych innych niż pozbawienie wolności. Dlatego też szybko się okazało, że działalność społeczna w zakresie wykonywania środków wol-

\footnotetext{
27 J. Skupiński, op. cit., s. 114-118.

${ }^{28}$ Rozporządzenie Ministra Sprawiedliwości z 3 marca 1965 r. w sprawie dozoru nad osobami, którym wykonanie kary pozbawienia wolności warunkowo zawieszono oraz w sprawie nadzoru nad osobami warunkowo zwolnionymi, Dz.U. nr 12, poz. 80.
} 
nościowych nie wystarcza i konieczne jest stworzenie zawodowej służby kuratorskiej, która by koordynowała i organizowała pracę kuratorów społecznych. Taką możliwość dawało właśnie rozporządzenie z 1965 r., w myśl którego w tym samym roku powołano 19 kuratorów zawodowych przy sądach wojewódzkich - liczbę tę zwiększono do końca tego roku do trzydziestu. Kolejne lata to stały przyrost kuratorów zawodowych: w 1970 r. było ich 124, w 1974 r. - 441. Nadal jednak zasadniczą część pracy kuratorskiej wykonywali społecznicy: w 1974 r. było ich niespełna 12 tys. (na jednego kuratora zawodowego przypadało ok. 27 kuratorów społecznych) ${ }^{29}$.

Lata sześćdziesiąte to również okres prac Komisji Kodyfikacyjnej nad nowym kodeksem karnym. Został on ostatecznie wprowadzony ustawą z dnia 19 kwietnia 1969 r., a zaczął obowiązywać od 1 stycznia $1970 \mathrm{roku}^{30}$. Ten akt prawny stał się podstawą modelu organizacyjnoprawnego kurateli sądowej dla dorosłych, który obowiązywał aż do 1986 roku.

\section{Krok czwarty - połączenie służb kuratorskich}

Na podstawie ustawy z 20 czerwca 1985 r. - Prawo o ustroju sądów powszechnych ${ }^{31}$, Minister Sprawiedliwości wydał rozporządzenie w sprawie kuratorów sądowych ${ }^{32}$. Ten akt prawny w szczególny sposób zaznaczył się w rozwoju kurateli sądowej w Polsce.

Przede wszystkim i po raz pierwszy $\mathrm{w}$ historii polskiej kurateli nastąpiło połączenie obu specjalności - w myśl cytowanego rozporządzenia kurator sądowy mógł być, po spełnieniu wymagań formalnych, albo kuratorem rodzinnym (czyli spełniającym swe czynności w wydziałach rodzinnych i nieletnich ${ }^{33}$ ), albo kuratorem dla dorosłych

\footnotetext{
29 J. Kamiński, S. Milewski, op. cit., s. 18-19; P. Stępniak, op. cit., s. 43-44.

30 Dz.U. $1970 \mathrm{nr}$ 13, poz. 94.

31 Dz.U. 1985 nr 31, poz. 137.

32 Rozporządzenie Ministra Sprawiedliwości z 24 listopada 1986 roku w sprawie kuratorów sądowych, Dz.U. 1986 nr 43, poz. 212.

$33 \S 2$ ust 2 cyt. Rozporządzenia.
} 
Paweł Sobierajski - Historia kurateli sq̨dowej...

(spełniającym swe czynności w wydziałach karnych sądów rejonowych i w wydziałach penitencjarnych ${ }^{34}$ ).

Kuratorzy pełnili swoje zadania zawodowo lub społecznie. Jeżeli chodzi o wymagania formalne, stawiane kandydatom na kuratora zawodowego, precyzował to zapis $\S 4$ :

1) posiadanie obywatelstwa polskiego,

2) pełnia praw cywilnych i obywatelskich oraz władzy rodzicielskiej,

3) niekaralność,

4) wiek powyżej 24 lat,

5) wykształcenie wyższe z zakresu pedagogiki, psychologii, socjologii (w wyjątkowych wypadkach - inne wyższe studia), bądź wykształcenie średnie w sytuacji, gdy kandydat legitymuje się praktyką z zakresu profilaktyki, resocjalizacji lub wychowania, 6) odbycie stażu kuratorskiego, 7) złożenie egzaminu kuratorskiego.

W przypadku kandydatów na kuratorów społecznych obowiązywały wymagania wyodrębnione w punktach 1-5 przytoczonego powyżej zapisu, z możliwością uwzględnienia osób w wieku powyżej 19 lat (po spełnieniu określonego warunku ${ }^{35}$ ).

Wprowadzono też (po raz pierwszy) funkcję kuratora wojewódzkiego - pierwowzór współczesnej funkcji kuratora okręgowego. Powoływał go prezes sądu wojewódzkiego spośród kuratorów specjalistów (wyjątkowo - spośród starszych kuratorów, wyróżniających się zdolnościami organizacyjnymi ${ }^{36}$ ).

Opisywane rozporządzenie z 1986 roku regulowało funkcjonowanie kurateli sądowej, dostarczając również istotnych informacji na temat praw i obowiązków kuratorskich, a także zagadnień o charakterze metodyczno-organizacyjnym. Trzeba jednak stwierdzić - mimo istotnego kroku naprzód w rozwoju tej instytucji - że status kuratora sądowego był nadal niedoprecyzowany i niejasny, na co wskazywał

\footnotetext{
$34 \S 2$ ust 1 cyt. Rozporządzenia.

35 Zob. § 32 cyt. Rozporządzenia.

36 Zob. \$18-21 cyt. Rozporządzenia.
} 
choćby zapis pierwszego paragrafu rozporządzenia: „Kuratorzy sądowi - zawodowi i społeczni - pełnią funkcje związane ze szczególną odpowiedzialnością za ochronę porządku i bezpieczeństwa publicznego w celu wychowania i resocjalizacji podopiecznych, wykonując w sądach powszechnych czynności o charakterze wychowawczo-resocjalizacyjnym i profilaktycznym oraz inne czynności określone w rozporządzeniu, a także w przepisach odrębnych" ${ }^{37}$.

Poza tym nadal, w myśl zapisów rozporządzenia, ale też i praktyki, funkcjonowała model kurateli społeczno-zawodowej, z zasadniczą dominacją liczby kuratorów społecznych w służbach kuratorskich.

Lata dziewięćdziesiąte XX wieku to czas dyskusji, propozycji na temat dalszej reformy kurateli sądowej, zorientowanej na profesjonalizację służb kuratorskich, autonomizację instytucji, dookreślenie jej zadań, zmianę charakteru kurateli z formalno-kontrolnego na wychowujący, unowocześnienie systemu wynagrodzeń. Pojawiły się też pierwsze propozycje ustawy, która miała uwzględniać te wszystkie przemyślenia, a także poprzez rangę tego aktu - nadać nową tożsamość kurateli sądowej.

W efekcie dyskusji środowiskowej, prac wielu zespołów konsultacyjnych oraz powołanych do tych celów komisji - w dniu 27 lipca 2001 roku Sejm RP uchwalił pierwszą w historii ustawę dotyczącą instytucji kurateli sądowej. Zamykając $w$ tym miejscu historyczny przegląd, pokazujący początki oraz istotne zdarzenia, konstytuujące instytucję kurateli sądowej w Polsce, zakończę cytatem z „Zarysu metodyki pracy kuratora sądowego", w którym autorzy tak opisują rzeczoną ustawę o kuratorach sądowych:

Ustawa o kuratorach sądowych stała się ukoronowaniem dążeń i zabiegów pokolenia kuratorów, które przez kilkanaście lat starało się o nadanie kuratorom takiej organizacji, która zapewniłaby efektywne działanie, preferowała potwierdzone praktycznie i naukowo procedury postępowania z podopiecznymi i mogła stanowić rzetelne wsparcie dla podopiecznych, sądu i ładu społecznego oraz która byłaby wreszcie godziwie wynagradzana za swoje działania. Ustawa stała się fundamentem tworzenia nowoczesnej, sprawnej,

$37 \S 1$ cyt. Rozporządzenia. Por. P. Stępniak , Funkcjonowanie..., op. cit., s. 51-52. 
Paweł Sobierajski - Historia kurateli sq̨dowej...

profesjonalnej i efektywnej służby kuratorskiej, zakorzenionej w polskiej tradycji kurateli sądowej dla nieletnich i myśli resocjalizacyjnej M. Grzegorzewskiej, C. Czapówa, S. Jedlewskiego, S. Górskiego ${ }^{38}$.

\section{Zakończenie}

Zamykając i uzupełniając ten krótki historyczny przegląd należy stwierdzić, iż - podobnie jak w większości innych krajów europejskich - rozwój kurateli sądowej w Polsce opierał się na rozwiązaniach belgijsko-francuskich, szczególnie jeśli chodzi o podłoże prawne dla tej instytucji. Tak jak w Belgii i Francji, powstanie kurateli sądowej w Polsce wiązało się z ukonstytuowaniem sądownictwa i kurateli dla nieletnich. Dopiero później, wraz ze zmianą polityki karnej w kierunku szerszego stosowania kar alternatywnych w stosunku do kary pozbawienia wolności, dostrzeżono potrzebę powołania instytucji kuratora sądowego dla dorosłych (taką możliwość stworzyło rozporządzenie Ministra Sprawiedliwości z 1958 r., a formalny kształt jednolitej zawodowej służby kuratorskiej uregulowało ostatecznie rozporządzenie z $1965 \mathrm{r}$.).

Dekret Naczelnika Państwa z 8 lutego 1919 r. w przedmiocie utworzenia sądów dla nieletnich był szczególny - wyznaczał szlak rozwoju instytucji kurateli sądowej, która przeżywała w swej 100-letniej historii lepsze i gorsze czasy. Swoistym i znamiennym momentem, kończącym ten przegląd, jest akt z lipca 2001 roku - on z kolei, w pełniejszy sposób, zaznaczył miejsce tej instytucji w polityce społecznej naszego państwa ${ }^{39}$.

Uchwalenie Ustawy o kuratorach sq̨dowych tak naprawdę nie kończy historii rozwoju kurateli sądowej w Polsce. Dowodem na to są mniejsze i większe zmiany w jej zapisach. Jej istotna nowelizacja planowana jest od kilku lat, choć z różnych powodów (znanych i niezna-

38 T. Jedynak, A. Martuszewicz, Od rozporządzenia do ustawy o kuratorach sq̨dowych, [w:] T. Jedynak, K. Stasiak (red.), Zarys metodyki pracy kuratora sqadowego, Wyd. Lexis-Nexis, Warszawa 2008, s. 62.

39 Będzie to przedmiotem odrębnego opracowania. 
nych) jest odwlekana ${ }^{40}$. Należy tylko żywić nadzieję, że będą to zmiany korzystne.

\section{Bibliografia:}

Holewiński S., $O$ warunkowem skazaniu, „Ateneum” 1897, t. III, s. 225-226, [za:] J Skupiński, Warunkowe skazanie w prawie polskim na tle porównawczym, Wyd. Polska Akademia Nauk, Warszawa 1992.

Jedynak T., Martuszewicz A., Od rozporzadzenia do ustawy o kuratorach sq̨owych, [w:] T. Jedynak, K. Stasiak (red.), Zarys metodyki pracy kuratora sqdowego, Wyd. Lexis-Nexis, Warszawa 2008, s. 62.

Kalinowski M., Nadzór kuratora sq̨dowego - formq wychowania resocjalizacyjnego, [w:] K. Pospiszyl (red.), Resocjalizacja nieletnich. Doświadczenia i koncepcje, WSiP, Warszawa 1990, s. 285.

Kamiński J., Milewski S., Resocjalizacja skazanych. Poradnik dla kuratorów sqdowych, Wydaw. Prawnicze, Warszawa 1979.

Komorowski A., Praktyczna działalność Koła Opiekunów Sądowych przy Sadzie dla nieletnich m. st. Warszawy, [w:] A. Komorowski, E. Neymark, Z. Rosenblum, $O$ sqdownictwie dla nieletnich $w$ Polsce, Dział Wydawnictw Związku Spółdzielni Spożywców, Warszawa 1928.

Korenfeld M., Zamiast kary, „Gazeta Sądowa Warszawska” 1889, nr 2, s. 17 i nast., [za: J Skupiński, Warunkowe skazanie..., op. cit.

Makarewicz J., Kodeks karny z komentarzem, Wyd. Zakładu Narodowego im. Ossolińskich, Lwów 1938.

Marek A., Rola amerykańskiej probacji i jej efektywność, „Acta Universitatis Nicolai Copernici. Prawo XVI" 1978, z. 89.

Marek A., Środki probacyjne, [w:] A. Marek et al. (red.), Prawo karne, Wyd. PWN, Warszawa 1986.

40 Zob. na ten temat m. in.: lista rozwiązań projektowych na stronach „Wykazu prac legislacyjnych i programowych Rady Ministrów", https://bip.kprm.gov.pl/kpr/ form/r7793828829424,Projekt-ustawy-o-kuratorskiej-sluzbie-sadowej.html [dostęp: 29-10-2019]; „Ministerstwo Sprawiedliwości pracuje nad projektem ustawy o kuratorskiej służbie sądowej", https://www.rp.pl/Sedziowie-i-sady/303079973-Minister stwo-Sprawiedliwosci-pracuje-nad-projektem-ustawy-o-kuratorskiej-sluzbie-sadowej. html [dostęp: 29-10-2019]; „Ustawa o kuratorach sądowych - planowana na trzeci kwartał 2019 r.", https://www.prawo.pl/prawnicy-sady/ustawa-o-kuratorach-sado wych-planowana-na-trzeci-kwartal-2019-r,420822.html [dostęp: 29-10-2019]. 
Paweł Sobierajski - Historia kurateli sq̨dowej...

Marzec-Holka K., Instytucja społecznych kuratorów sq̨dowych $w$ świetle badań, Wyd. Wyższa Szkoła Pedagogiczna, Bydgoszcz 1994.

Mościskier A., System kuratorski i opieki postpenitencjarnej w Anglii i Walii, „Prace Instytutu Profilaktyki Społecznej i Resocjalizacji UW” 1985, t. 9.

Skupiński J., Warunkowe skazanie w prawie polskim na tle porównawczym, Wyd. Polska Akademia Nauk, Warszawa 1992.

Sobierajski P., „Socjalno-wychowawcze aspekty kurateli sądowej dla dorosłych (w świetle opinii kuratorów)”, niepublikowana rozprawa doktorska, promotor: prof. dr hab. Andrzej Olubiński, Toruń 1999.

Stasiak K., Ewolucja kurateli sq̨dowej od poczq̨tku do wejścia w życie rozporzq̨dzenia z 1986 r., [w:] T. Jedynak, K. Stasiak (red.), Zarys metodyki pracy kuratora sqdowego, Wyd. Lexis-Nexis, Warszawa 2014.

Stępniak P., Funkcjonowanie kurateli sq̨dowej. Teoria a rzeczywistość, Wyd. UAM, Poznań 1992.

Szymków K., Instytucja stałych opiekunów sq̨dowych 1919-1929, „Folia Iuridica Universitatis Wratislaviensis" 2018, vol. 7 (1), s. 70-75.

\section{Akty prawne przywołane w tekście (chronologicznie):}

Dekret Naczelnika Państwa z 8 lutego 1919 r. w przedmiocie utworzenia sądów dla nieletnich, Dz.Pr.P.P. 1919 Nr 14, poz. 171.

Rozporządzenie Ministra Sprawiedliwości z 26 lipca 1919 r. w przedmiocie urządzenia sądów dla nieletnich, Dz.Pr.P.P. 1919 Nr 63, poz. 378.

Rozporządzenie Ministra Sprawiedliwości z dnia 25 czerwca 1929 r. w sprawie przekształcenia instytucji opiekunów sądowych na kuratorów nieletnich przy sądach grodzkich i przy sądach dla nieletnich, Dz.U. nr 47, poz. 387.

Rozporządzenie Prezydenta RP z 11 lipca 1932 r. - Kodeks karny, Dz.U. RP nr 60, poz. 571.

Rozporządzenie Ministra Sprawiedliwości z dnia 3 lipca 1956 r. o inspektorach społecznych przy sądach powiatowych, Dz.U. 1956, Nr 29, poz. 134.

Ustawa z 29 maja 1957 r. o warunkowym zwolnieniu osób odbywających karę pozbawienia wolności, Dz.U. nr 31, poz. 134.

Rozporządzenie Ministra Sprawiedliwości z 15 stycznia 1958 r. w sprawie nadzoru nad warunkowo zwolnionymi, Dz.U. nr 10, poz. 35.

Rozporządzenie Ministra Sprawiedliwości z 13 lutego 1959 r. o kuratorach sądowych dla nieletnich, Dz.U. 1959, Nr 18, poz. 113. 
Rozporządzenie Ministra Sprawiedliwości z 1 kwietnia 1959 r. w sprawie wynagradzania kuratorów zawodowych dla nieletnich, Dz.U. 1959, Nr 26, poz. 164.

Zarządzenie Ministra Sprawiedliwości z 10 kwietnia 1959 r. - Instrukcja w sprawie kuratorów sądowych dla nieletnich, Zbiór resortowych aktów prawnych Ministerstwa Sprawiedliwości, tom I, poz. 121, Cyt. za: K. Stasiak, Ewolucja kurateli sq̨dowej od poczq̨tku do wejścia w życie rozporzqdzenia z 1986 r., [w:] T. Jedynak, K. Stasiak (red.), Zarys metodyki pracy kuratora sądowego, Wyd. Lexis-Nexis, Warszawa 2014.

Rozporządzenie Ministra Sprawiedliwości z 3 marca 1965 r. w sprawie dozoru nad osobami, którym wykonanie kary pozbawienia wolności warunkowo zawieszono oraz $\mathrm{w}$ sprawie nadzoru nad osobami warunkowo zwolnionymi, Dz.U. nr 12, poz. 80.

Ustawa z dnia 19 kwietnia 1969 r. - Kodeks karny, Dz.U. 1970 nr 13, poz. 94.

Rozporządzenie Ministra Sprawiedliwości z 3 maja 1973 r. w sprawie kuratorów nieletnich, Dz.U. 1973, Nr 18, poz. 107.

Ustawa z 20 czerwca 1985 r. - Prawo o ustroju sądów powszechnych, Dz.U. 1985 nr 31, poz. 137.

Rozporządzenie Ministra Sprawiedliwości z 24 listopada 1986 roku w sprawie kuratorów sądowych, Dz.U. 1986 nr 43, poz. 212.

\section{Netografia:}

„Wykaz prac legislacyjnych i programowych Rady Ministrów”, https://bip.kprm.gov.pl/kpr/form/r7793828829424,Projekt-ustawy-okuratorskiej-sluzbie-sadowej.html [dostęp: 29-10-2019].

„Ministerstwo Sprawiedliwości pracuje nad projektem ustawy o kuratorskiej służbie sądowej", https://www.rp.pl/Sedziowie-i-sady/303079973Ministerstwo-Sprawiedliwosci-pracuje-nad-projektem-ustawy-okuratorskiej-sluzbie-sadowej.html [dostęp: 29-10-2019].

„Ustawa o kuratorach sądowych - planowana na trzeci kwartał 2019 r.”, https://www.prawo.pl/prawnicy-sady/ustawa-o-kuratorach-sadowychplanowana-na-trzeci-kwartal-2019-r,420822.html [dostęp: 29-10-2019]. 